\title{
Comparison of Different Techhiques for Determining Plate Counts of Marine Bacteria
}

\author{
Usio Simidu, Won Jae LeE, and Kazuhiro Kogure*
}

(Accepted November 17, 1982)

\begin{abstract}
For seawater samples from various environments, viable bacterial counts obtained by various plate count techniques were compared with each other and with direct viable counts and total counts. Of the three plate count methods, i.e., spread plate, filter and pour plate methods, the filter method gave the lowest number of colony forming units. Average percentages of the number of colony forming units obtained by the filter method to the number obtained by the spread plate method ranged from $5.2 \%$ for samples from Tokyo Bay to $26 \%$ for samples from open seawater of the Pacific Ocean and the South China Sea. The pour plate method using agar media of low gelling temperature yielded about $90 \%$ of the number of colony forming units obtained by the spread plate method. The colony forming units in the pour plate method decreased in number by about $20 \%$ when the temperature of molten agar media was raised from $37^{\circ} \mathrm{C}$ to $40^{\circ} \mathrm{C}$. The pour plate method with agar media of low gelling temperature has an advantage over the spread plate method when water samples from open seas, in which low numbers of colony forming units can be expected, are to be examined.
\end{abstract}

The plate count technique using an agar medium has long been established as a standard method for the enumeration and isolation of bacteria in marine bacteriology as well as in freshwater and soil bacteriology, although application of the method in these fields is rather limited compared with its extensive use in food microbiology. The numbers of viable bacteria obtained from plate counts are less than those obtained by the MPN method ${ }^{1)}$ or Kogure's method of direct viable counts. ${ }^{2}$ ) However, the precision of the plate count method is better than the MPN method. Besides, agar plate methods are more practical than the MPN technique when large numbers of samples are to be examined, and when many bacterial cultures are to be isolated, and hence they have been used extensively in ecological studies of marine bacterial populations.

After the classical works of ZoBell on cultural conditions for plate counts of marine bacteria, ${ }^{3}$ ) few comprehensive examinations of the method have been reported, although studies on the evaluation and improvement of the media have been published by several workers. ${ }^{4-9)}$ Since the development of the membrane filter, filter techniques using filters made of cellulose derivatives and polycarbonate have been regarded as the standard methods for plate counts of seawater samples, al- though the spread plate method has also been used for water samples from coastal environments.

A comparative re-examination of various plate count mehtods, results of which are given in the present paper, showed that, for both coastal and pelagic water samples, filter methods give much lower viable bacterial counts, i.e., number of colony forming units, compared with spread plate or pour plate techniques.

\section{Methods}

Seawater samples from Tokyo Bay and Sagami Bay (Station A-1, $35^{\circ} 00^{\prime} \mathrm{n}, 139^{\circ} 20 \mathrm{fE}$ ) were collected during the KT-81-12 cruise aboard R/V TANSEIMARU in July, 1981, while samples from the Pacific Ocean along the Nansei Shoto (Station $2,25^{\circ} 58^{\prime} \mathrm{N}, 130^{\circ} 00^{\prime} \mathrm{E}$ ) and from the South China Sea (Station 4, $21^{\circ} 00^{\prime} \mathrm{N}, 119^{\circ} 01^{\prime} \mathrm{E}$; Station 5, $18^{\circ} 05^{\prime} \mathrm{N}, 117^{\circ} 00^{\prime} \mathrm{E}$; Station $6,14^{\circ} 41^{\prime} \mathrm{N}, 114^{\circ} 10^{\prime} \mathrm{E}$ ) were obtained during the $\mathrm{KH}-81-5$ cruise aboard R/V HAKUHOMARU in September, 1981. Samples were collected at various depths using Niskin bags. Inoculation of the samples onto agar plates and in MPN tubes was carried out on board ship immediately after sample collection.

Subsamples of each sample were taken for the determination of total bacterial counts and direct

* Ocean Research Institute, University of Tokyo, Minamidai, Nakano 164, Tokyo, (清水湖・李原在・ 木幕一辟: 巢京大学海洋研究所)。 
viable counts. Total counts were determined by an epifluorescent method following HoBBJE $e t a^{10}{ }^{10}$ and direct viable counts were obtained following the method of KOGURE et al..$^{2)}$ For the plate counts, PPES-II medium, ${ }^{p)}$ ORI medium and diluted ORI media were used. ORI medium contains $1 \mathrm{~g}$ Proteose Peptone No. 3 (Difco), $0.5 \mathrm{~g}$ Bacto Yeast Extract (Difco), $0.5 \mathrm{~g}$ Phytone (BBL), $0.2 \mathrm{~g} \mathrm{Na}_{2} \mathrm{~S}_{2} \mathrm{O}_{3} \cdot 5 \mathrm{H}_{2} \mathrm{O}, 0.05 \mathrm{~g} \mathrm{Na}_{2} \mathrm{SO}_{8}$ and $0.04 \mathrm{~g}$ Ferric citrate in a mixture of $100 \mathrm{ml}$ of distilled water and $900 \mathrm{~m} l$ of seawater $(\mathrm{pH} \mathrm{7.6)}$. Diluted media ORI/10 and ORI/100 were prepared so as to contain respectively $1 / 10$ and $1 / 100$ of the concentration of nutrient in the ORI medium. To the media for spread plate and filter methods, Bacto Agar (Difco) was added in the concentration of $15 \mathrm{~g} / l$. For the filter method, Nuclepore filters, $47 \mathrm{~mm}$ in diameter and with a pore size of $0.2 \mu$, (GE Co. Ltd.) and Millipore filters of HA type (Millipore Co. Ltd.) were used. According to the depth and sampling area, 0.5 to $100 \mathrm{~m} l$ of seawater sample was filtered. For the spread plate method, 0.1 to $0.5 \mathrm{~m} l$ of the sample was dropped onto an agar plate. Samples from Tokyo Bay were diluted with sterilized seawater so that $0.1 \mathrm{~m} /$ of the diluted sample gave the desired count.

In addition to the spread plate and filter methods, the pour plate method was also tested in this study. The agar media for the pour plate method were prepared with a 1:1 mixture of Agarose type VII (Sigma) and Agar AG-202-1 (Wako). The gelling temperatures of a 1.5 per cent solution of Agarose type VII and Agar AG-202-1 are claimed by the manufacturers to be less than $30^{\circ} \mathrm{C}$ for the former and $36^{\circ} \mathrm{C}$ for the latter. The molten agar media were held in a water bath at a temperature of either $37^{\circ} \mathrm{C}$ or $40^{\circ} \mathrm{C}$. One or two milliliters of seawater sample was placed on one side of a sterile plastic petri dish ( $9 \mathrm{~cm}$ in diameter), and $12 \mathrm{ml}$ of molten agar medium was added to the other side of the dish, and then they were mixed thoroughly.

All the platings were made in duplicate, and the results were determined after 14 days incubation at $20^{\circ} \mathrm{C}$.

For the MPN method, two different media, M and $\mathrm{D}$ medium, were used. The composition of these media are given in Table 1 . The nutrient concentration of the $\mathrm{M}$ medium is too low to observe the turbidity caused by bacterial growth. Hence, after 7 days incubtion of the tubes which had been inoculated with seawater samples, $2 \mathrm{~m} l$ of the culture was transfered to the top of a diluted shake agar medium which contained the same
Table 1. Composition of media for the MPN method

\begin{tabular}{|c|c|c|}
\hline & D & $\mathrm{M}$ \\
\hline $\begin{array}{l}\text { Proteose Peptone No. } 3 \\
\text { (Difco) }\end{array}$ & $50 \mathrm{mg}$ & $1 \mathrm{mg}$ \\
\hline $\begin{array}{l}\text { Bacto Yeast Extract } \\
\text { (Difco) }\end{array}$ & 50 & 1 \\
\hline Ferric citrate $\ldots \ldots \ldots \ldots$ & 5 & 0.1 \\
\hline Glucose $\ldots \ldots \ldots \ldots$ & 2.5 & 0.5 \\
\hline Mannitol $\ldots \ldots \ldots \ldots \ldots$ & 2.5 & 0.5 \\
\hline Sodium acetate ........ & 2.5 & 0.5 \\
\hline Sodium malate..$\ldots \ldots$. & 2.5 & 0.5 \\
\hline Distilled water . . & $100 \mathrm{ml}$ & $100 \mathrm{ml}$ \\
\hline Aged seawater $\ldots \ldots \ldots$. & $\begin{array}{l}900 \\
\text { pH } 7.6\end{array}$ & $\begin{array}{l}900 \\
\mathrm{pH} 7.6\end{array}$ \\
\hline
\end{tabular}

ingredients as $\mathrm{D}$ medium except that the agar concentration was reduced to $3 \mathrm{~g}$ per liter. The growth of the bacteria on the shake culture was observed for up to 14 days. The rest of the $\mathrm{M}$ medium culture was examined using the epiffuorescent technique. The growth of bacteria observed by both methods was similar, showing that the bacteria, once grown in $\mathrm{M}$ medium, also succeeded in growing on the shake medium of higher nutrient concentration.

\section{Results}

The results of different plate counts for samples from Tokyo Bay and Sagami Bay (Table 2) indicate that the filter method gave far smaller numbers of colonies than the spread plate and pour plate methods. The average percentage of counts obtained by the filter method to those obtained by the spread method was $5.2 \%$ for the samples from Tokyo Bay and $12.6 \%$ for the samples from Sagami Bay. A higher percentage $(25.9 \%)$ was obtained by the filter method for samples from open seas (Table 3 and 4, calculated for ORI and ORI/10 media).

The viable counts, i.e. number of colony forming units, obtained by the pour plate method were generally lower than those obtained by the spread plate method, though they were still much higher than the counts obtained by the filter method. The lower of the two temperatures used for keeping the molten agar medium $\left(37^{\circ} \mathrm{C}\right)$ before pouring gave higher numbers of colony forming units.

The bacterial numbers obtained by various methods; direct counts, the MPN technique and agar plate methods are compared in Table 5 . The results show that the viable counts obtained by the spread plate method were comparable to those 
Table 2. Plate counts of seawater samples from Tokyo Bay and Sagami Bay

\begin{tabular}{|c|c|c|c|c|c|c|c|}
\hline \multirow{2}{*}{ Station } & \multirow{2}{*}{ Depth } & \multirow{2}{*}{ Media } & \multicolumn{2}{|c|}{ Spread plate } & \multicolumn{2}{|c|}{ Filter } & \multirow{2}{*}{$\begin{array}{c}\text { count } / \mathrm{ml} \\
\text { Pour } \\
\text { plate- } 40^{* 2} \\
\% \text { to } \mathrm{A}\end{array}$} \\
\hline & & & Count (A) & $\%$ to A & $\begin{array}{l}\mathrm{NC}^{* 1} \\
\% \text { to A }\end{array}$ & $\begin{array}{l}M L^{* 1} \\
\% \text { to } A\end{array}$ & \\
\hline \multirow{4}{*}{$T-2 * 3$} & \multirow[t]{2}{*}{$0 \mathrm{~m}$} & $\overline{O R I}$ & $2.7 \times 10^{5}$ & 100 & 2.2 & 3.1 & 59.3 \\
\hline & & ORI $/ 10$ & $2.1 \times 10^{5}$ & 100 & 6.2 & 6.7 & 71.4 \\
\hline & \multirow[t]{2}{*}{$10 \mathrm{~m}$} & ORI & $3.1 \times 10^{4}$ & 100 & 6.5 & 9.0 & 80.6 \\
\hline & & ORI $/ 10$ & $6.9 \times 10^{4}$ & 100 & 4.9 & 3.0 & 29.0 \\
\hline \multirow{4}{*}{$A-1^{* 3}$} & \multirow[t]{2}{*}{$0 \mathrm{~m}$} & ORI & $1.3 \times 10^{3}$ & 100 & 10.8 & 6.2 & \multirow[t]{2}{*}{30.8} \\
\hline & & ORI/10 & $1.1 \times 10^{3}$ & 100 & 2.3 & 1.1 & \\
\hline & \multirow[t]{2}{*}{$100 \mathrm{~m}$} & ORI & $6.5 \times 10^{1}$ & 100 & 16.9 & 35.4 & \multirow[t]{2}{*}{76.9} \\
\hline & & ORI/10 & $1.4 \times 10^{2}$ & 100 & 12.1 & 15.7 & \\
\hline
\end{tabular}

-1 NC: Nuclepore filter, GE Co., pore size 0.2 S; ML: Millipore filter, Millipore Co., type HA.

*2 Molten agar was held at $40^{\circ} \mathrm{C}$ before pouring.

* 3 T-2: inner Tokyo Bay, A-1 : central area of Sagami Bay.

Table 3. Comparison between spread plate and filter methods for seawater samples from the South China Sea

\begin{tabular}{|c|c|c|c|c|c|c|c|c|c|c|}
\hline \multirow{2}{*}{\multicolumn{2}{|c|}{ Station Depth }} & \multirow[b]{2}{*}{ count (A) } & \multicolumn{2}{|c|}{$\begin{array}{c}\text { ORI } \\
(2,000 \mathrm{mg} / l)^{* 1}\end{array}$} & \multicolumn{2}{|c|}{$\begin{array}{c}\text { PPES-II } \\
(5,100 \mathrm{mg} / l)^{* 1}\end{array}$} & \multicolumn{2}{|c|}{$\begin{array}{c}\text { ORI } / 10 \\
(200 \mathrm{mg} / l)^{* 1}\end{array}$} & \multicolumn{2}{|c|}{$\begin{array}{c}\text { count } / \mathrm{ml} l \\
\text { ORI } / 100 \\
(20 \mathrm{mg} / l)^{* 1}\end{array}$} \\
\hline & & & 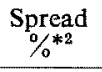 & $\begin{array}{l}\text { Filer } \\
\% * 2\end{array}$ & $\underset{\% * 2}{\text { Spread }}$ & $\begin{array}{c}\text { Filter } \\
\% * 2 \\
0\end{array}$ & $\begin{array}{c}\text { Spread } \\
\% * 2\end{array}$ & $\begin{array}{c}\text { Filter } \\
\% * 2 \\
\end{array}$ & $\underset{\%}{\text { Spread }}$ & $\begin{array}{r}\text { Filter } \\
\% * 2 \\
\end{array}$ \\
\hline \multirow{3}{*}{ St 5} & $0 \mathrm{~m}$ & 215 & 100 & 69.7 & 85.1 & 59.1 & 95.6 & 61.4 & 128 & 55.8 \\
\hline & $100 \mathrm{~m}$ & 53 & 100 & 8.7 & 47.2 & 7.2 & 47.2 & 3.8 & 28.3 & 4.2 \\
\hline & $600 \mathrm{~m}$ & 16 & 100 & 10.6 & 37.5 & 9.4 & 25.0 & 10.0 & 12.5 & 6.9 \\
\hline \multirow[t]{3}{*}{ St 6} & $0 \mathrm{~m}$ & 155 & 100 & 26.5 & 102 & 23.2 & 87.1 & 31.6 & 83.9 & 21.9 \\
\hline & $100 \mathrm{~m}$ & 80 & 100 & 9.4 & 63.8 & 9.6 & 97.5 & 12.5 & 9.4 & 5.6 \\
\hline & Average & & 100 & 25.0 & 67.1 & 21.7 & 704 & 23.9 & 52.4 & 18.9 \\
\hline
\end{tabular}

*1 Amount of organic nutrients in the medium is given in parentheses.

*2 Percentage with respect to $A$.

Table 4. Comparison between spread plate and pour plate counts for seawater samples from the Pacific Ocean and the South China Sea

\begin{tabular}{|c|c|c|c|c|c|c|c|}
\hline \multirow{2}{*}{ Depth } & \multirow{2}{*}{ Station } & \multirow{2}{*}{ Medium } & \multicolumn{2}{|c|}{ Spread } & \multirow{2}{*}{$\begin{array}{l}\text { Filter } \\
\% \text { to A }\end{array}$} & \multicolumn{2}{|c|}{ Pour } \\
\hline & & & count (A) & $\%$ to $\mathrm{A}$ & & $40 \mathrm{C} \%$ to $\mathrm{A}$ & $37 \mathrm{C} \%$ to $\mathrm{A}$ \\
\hline \multirow[t]{2}{*}{$0 \mathrm{~m}^{*}$} & $2,4,6$ & ORI & $113-115$ & 100 & 25.2 & 100.0 & 107.7 \\
\hline & & ORI $/ 10$ & $95-135$ & 100 & 38.0 & 63.0 & 76.2 \\
\hline \multirow[t]{2}{*}{$100 \mathrm{~m}^{*}$} & $2,4,6$ & ORI & $15-85$ & 100 & 27.6 & 126.7 & 133.3 \\
\hline & & ORI $/ 10$ & $20-78$ & 100 & 24.2 & 45.8 & 85.7 \\
\hline \multirow[t]{2}{*}{$400 \mathrm{~m}$} & 2 & ORI & 3 & 100 & 34.7 & 66.7 & 133.3 \\
\hline & & ORI $/ 10$ & 4 & 100 & 30.0 & 50.0 & 75.0 \\
\hline \multirow[t]{2}{*}{$600 \mathrm{~m}$} & 4 & ORI & 8 & 100 & 5.8 & 25.0 & 47.5 \\
\hline & & ORI $/ 10$ & 5 & 100 & 10.0 & 46.0 & 90.0 \\
\hline \multirow[t]{2}{*}{$1,200 \mathrm{~m}$} & 2 & ORI & 7 & 100 & 14.3 & 40.0 & 50.0 \\
\hline & & ORI $/ 10$ & 6 & 100 & 16.7 & 30.0 & 41.7 \\
\hline
\end{tabular}

* Average percentages for three sampling stations.

obtained by the MPN method with D medium. When more dilute $M$ medium was used, however, numbers of growing bacteria in the samples in- creased by as much as 14 times, though the magnitude of the increase depended on the sampling location. 
Table 5. Bacterial numbers of seawater samples from the South China Sea counted by different methods

count $/ \mathrm{m} l$

\begin{tabular}{|c|c|c|c|c|c|c|c|}
\hline \multirow{2}{*}{ Station } & \multirow{2}{*}{ Depth } & \multirow{2}{*}{$\begin{array}{l}\text { Total } \\
\text { count }\end{array}$} & \multirow{2}{*}{$\begin{array}{l}\text { Direct } \\
\text { viable } \\
\text { count }\end{array}$} & \multicolumn{2}{|c|}{ MPN } & \multicolumn{2}{|c|}{ Plate count* } \\
\hline & & & & $M$ medium & D medium & Spread & Filter \\
\hline \multirow{3}{*}{ St 4} & $0 \mathrm{~m}$ & $1.2 \times 10^{\circ}$ & $8.2 \times 10^{4}$ & $3.3 \times 10^{8}$ & $3.0 \times 10^{2}$ & $1.6 \times 10^{2}$ & $3.9 \times 10^{1}$ \\
\hline & $100 \mathrm{~m}$ & $6.9 \times 10^{5}$ & $5.4 \times 10^{8}$ & $5.3 \times 10^{2}$ & $3.7 \times 10^{1}$ & $5.5 \times 10^{1}$ & $6.6 \times 10^{0}$ \\
\hline & $600 \mathrm{~m}$ & $2.0 \times 10^{5}$ & $2.4 \times 10^{3}$ & $1.6 \times 10^{1}$ & $2.0 \times 10^{\circ}$ & $8.0 \times 10^{\circ}$ & $4.6 \times 10^{-1}$ \\
\hline \multirow{3}{*}{ St 5} & $0 \mathrm{~m}$ & $9.1 \times 10^{5}$ & $4.2 \times 10^{4}$ & $1.7 \times 10^{2}$ & $1.7 \times 10^{2}$ & $2.1 \times 10^{2}$ & $1.5 \times 10^{2}$ \\
\hline & $100 \mathrm{~m}$ & $6.5 \times 10^{3}$ & $2.1 \times 10^{4}$ & $7.9 \times 10^{1}$ & $7.1 \times 10^{1}$ & $5.3 \times 10^{1}$ & $4.6 \times 10^{0}$ \\
\hline & $600 \mathrm{~m}$ & $2.6 \times 10^{5}$ & $2.8 \times 10^{3}$ & $2.8 \times 10^{1}$ & $1.7 \times 10^{1}$ & $1.6 \times 10^{1}$ & $1.7 \times 10^{0}$ \\
\hline
\end{tabular}

* ORI medium.

\section{Discussion}

One of the reasons for the spread plate method giving higher viable counts than the filter method is the occurrence of bacterial clumps in the seawater samples. Aggregates on the agar plates will be broken, at least to some extent, by the process of spreading with a glass rod, and hence the number of potential colony forming units will increase. However, the higher counts obtained by the pour plate method compared with the filter method, seem to show that, apart from the occurrence of bacterial clumps, there are some other factors that cause low viable counts in the filter method. Although at present there is no direet evidence of inhibition of bacterial growth on the surface of filters, limited supply of water and nutrients to the surface, and slower diffusion of bacterial metabolites my be factors which adversely affect bacterial growth on filters. Another factor that may affect the growth is exposure to atmospere.

The spread plate technique gave the highest plate counts in the present experiments, although the differences in counts between the spread plate and pour plate methods were not so great as in the experiments of Buck and Cleverdon, ${ }^{1)}$ who used agar medium held at a higher temperature of $45^{\circ} \mathrm{C}$. In the present experiments, the counts obtained by the spread plate method are not reliable for samples from the deeper layers of open seas, since the number of colonies developed on the plates were often small and variable. Plating on board $R / V$ HAKUHO-MARU was carried out in a room equipped with an air filtration device, and control plates, on which distilled water was spread instead of seawater samples, gave no colonies. However, when the number of colony forming units in water samples is less than 8 or 10 per milliliter, the spread plate method apparently becomes inadequate. In the usual procedure for the spread plate method, the amount of water sample applied to the plate is limited to $0.2 \mathrm{~m} l$, since addition of $0.5 \mathrm{~m} /$ of sample often causes trouble in drying the plates before incubation. On the other hand, with the pour plate method, $2 \mathrm{~m} l$ of water sample can easily be mixed with $12 \mathrm{ml}$ of molten agar medium. This imparts a decided advantage to the pour plate method when deeper water samples are analysed. since the number of colony forming bacteria in such samples is rather critical for successful incubation.

The ratio of colony forming units obtained by the pour plate method to those obtained by the spread plate method was low for the samples taken from deeper waters $(600$ and $1,200 \mathrm{~m})$. Bacteria in deeper waters may be more sensitive to the temperature of the molten agar. A lower temperature of molten agar in the pour plate technique is apparently desirable. However, Agarose type VII (Sigma) has rather low gell strength and water holding capacity at a concentration of $15 \mathrm{~g}$ per liter, and this often caused spreading of the bacterial colonies at the agar-plate boundary. Also, the Agarose plate tended to liquify easily when agar digesting bacteria were present in the water samples. Further experiments are necessary to select suitable agar preparations and to determine the agar concentration which gives the best balance of low gelling temperature and high gell strength most suitable for the pour plate count of seawater samples.

In the present experiments, bacterial counts obtained by the spread plate and pour plate methods were comparable to those obtained by the MPN method with D medium, though the MPN method with more dilute $M$ medium gave higher counts, due apparently to the presence of oligotrophic bacteria, which were greater in number than the ordinary heterotrophic bacteria. The direct viable counts, however, were still higher 
than the MPN counts by 1 to 2 orders of magnitude. Theoretically, closer bacterial numbers would be expected between the direct viable count and MPN methods, since in both methods bacteria are cultivated in seawater media without agar. The natural seawater used in the direct viable counts as opposed to the heat sterilized seawater used in the MPN method may have favored the growth of marine bacteria in the direct count method. Also the occurrence of bacterial clumps, which can be counted as separate bacterial cells in the direct viable count method, may have resulted in lower counts in the MPN method.

\section{Acknowledgements}

The authors thank to the officers and crew of R/V TANSEI-MARU and HAKUHO-MARU for assistance in collecting samples.

\section{References}

1) H.W. JANNASCH and G. E. Jones: Limnol.
Oceanogr, 4, 128-139 (1959).

2) K. Kogure, U. Simidu, and N. Taga: Can. J. Microbiol., 25, 415-420 (1979).

3) C. E. ZoBell: J. Mar. Res. 4, $42-57$ (1941).

4) J. A. Baross, F. J. Hanus, and R. Y. Morita: in "Effect of the Ocean Environment on Microbial Activities" (ed. by R. R. Colwell and R. Y. MorrTA), University Park Press, Baltimore, 1974, pp. 182-202.

5) A. F. Carlucci and D. Pramer: Proc. Soc. Expt. Biol. Med., 96, 392-394 (1957).

6) J. A. GORBENKo: Mikrobiol., 30, 168-172 (1961).

7) R. Goulder: J. Appl. Bacteriol., 41, 353-355 (1976).

8) U. Simidu: in "Effect of the Ocean Environment on Microbial Activities" (ed. by R. R. Colwell and R. Y. Morita), University Park Press, Baltimore, 1974, pp. 249-257.

9) N. TAGA: Bull. Misaki Mar. Biol. Inst. Kyoto Univ., 12, 45-65 (1968).

10) J. E. Hobbie, R. J. Daley, and S. JASper: Appl. Environ. Microbiol., 33, 1225-1228 (1977).

11) J. D. BuCK and R.C. Cleverdon: Limnol. Oceanogr. 5, 78-80 (1960). 